\title{
Conceptualization of the labor market and public administration. Public administration in Albania.
}

\author{
Romeo Terolli ${ }^{1}$ \\ South East European University, Macedonia
}

\begin{abstract}
The focus of this study is the conceptualization of the labor market, public administration and public administration sector in the Republic of Albania.

The purpose of this research paper is to identify the main theories of the labor market, to identify the main approaches to the concept of public administration and to analyze the most important aspects of the functioning of public administration in Albania.

The methodology used in this paper is a mixture of qualitative and analytical method. These methods will be first used to analyze and identify the main theories of the labor market, second to identify the main definitions of public administration and third to analyze the most important elements of public administration in the Republic of Albania.

The labor market mostly refers to the public or private space in which the employee-employer relationship is built and a service is obtained. Public administration is an integral part of the labor market, more specifically it constitutes its public space, serving as a regulator for all social activities that take place in it. In the Republic of Albania, public administration accounts for $14.4 \%$ of the workforce. The main principles of public administration in the Republic of Albania are supported through the legal basis which guarantee the functionality and implementation of its public activity.
\end{abstract}

Keywords: administration, Albania, labor market, public.

\section{Introduction}

This paper will conceptualize two basic concepts for a country's economy such as the labor market and public administration. Conceptualizing these two concepts is crucial to the understanding of their definitions and how they affect each other. To concretize these concepts, the case of public administration in the Republic of Albania will be studied with some of the most important elements that determine its functionality.

In a nutshell, the labor market is "the number of people available for work in relation to the number of jobs available" (Oxford Dictionary 2020, online). The labor market mostly refers to a public or private space where the relationship between the employee and the employee is built. Public administration, on the other hand, is part of the labor market and constitutes the 


\section{6th International Conference on New Findings ON HUMANITIES AND SOCIAL SCIENCES}

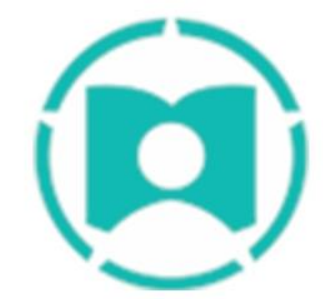

20 - 22 August 2021

Dublin, Ireland

majority of a country's public service network. To be exact, etymologically, the word "administration" is derived from the old Latin "administration" which means "to serve" (Dobjani E. 2007, pp.10). Whereas with the word "public" we will understand the mediating sphere between the society and the state in which the citizens (public) are the bearers of public opinion (Pajaziti, 2009, pp.525).

Public administration in the Republic of Albania constitutes the set of rules and norms that define the management of public service delivery. This administration is based on several principles such as: accountability; responsibility, cooperation, efficiency and effectiveness which guarantee its functionality.

As mentioned above, the issues addressed in this paper are:

- conceptualization of the labor market,

- conceptualization of public administration

- aspects of the functioning of public administration in Albania.

\section{Labor market}

The labor market refers to labor supply and demand. This concept also approximates the neoclassical theory of the labor market according to which the labor market predicts the interaction of supply and demand to determine the optimal combination between income and employment (Smith 2003, pp.2). In modern societies the labor market implies the relationship between employer and employee (Fincham \& Rhodes, 1988, pp.213).

A key element for employees in the job market is the preference to choose from. If a job were to be rationally divided in a market, then employers would have the maximum choice, which would allow them to adapt the requirements of the job position to the skills of the employees. Didier (1997) defines the labor market as a means of communication through which sellers and buyers will have to inform each other about what they own, what they need and the prices they ask for or propose, before closing a transaction. Through this definition it can be concluded that in fact the labor market requires certain elements such as the product being sold, the seller of the product, the buyer of the product and the agreement reached between the parties. Beligrădeanu and Stefănescu (1997) describe the labor market as the juxtaposition of labor supply and demand in a given time span and in a geographical area that usually ends through employment (with an individual employment contract). In this definition two other notions are distinguished such as time space and geographical space. The same work in one time space and another geographical space the meaning of supply and demand would have a different value. It is important to understand that these concepts as buyers or sellers are not abstract. First and foremost employees are not an abstract object but are human beings who have families, desires and needs (Samuelson and Nordhaus, 2001). One of the reasons that the socio-economic preferences of public administration employees are also studied is the fact that administration without employees constitutes an abstract concept or can only be identified through the physical space represented by a particular institution. The functionality of public administration is not provided by physical facilities but by individuals who provide services. 


\section{6th International Conference on New Findings ON HUMANITIES AND SOCIAL SCIENCES}

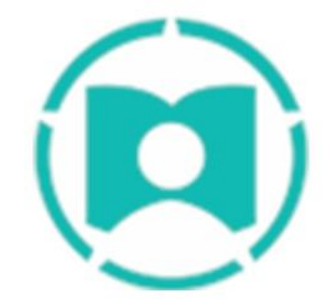

20 - 22 August 2021

Dublin, Ireland

Back to the concept of the labor market, we must keep in mind that the exchange relationship between two individuals requires that the wishes, requirements and needs of each party be taken into account. In separate studies, the labor market is seen from two other perspectives. The first is that work is like all the goods or services through which individuals sell work in exchange for wages while the second approach which values work as a commodity unlike the rest of the goods and services that refer more to the supply of manpower available in the labor market. (Hudson, 2000). The concept of work.i is common to these two approaches. What separates them, is the way in which the work itself is contextualized; in the first case it is equated with any good or service while in the second case it is separated from any other good or service. Different groups operating within the labor market present different working conditions, different promotional opportunities, different wages and different market institutions (Reich M. et al, 1973). Divisions within the labor market revolve around key theories (Cojuhari \& Dorofeev, 2014). The first is the classical theory represented by Adam Smith, Jean Baptiste Say, John Stuart Mill, which is based on the general equilibrium between supply and demand for labor. According to this theory there is a belief that there is no unemployment. Unemployment is simply temporary and comes as a result of the labor market. This kind of unemployment is natural according to these authors. According to them, occasions when there is a difference between supply and demand, are regulated through salary increases. According to neoclassical theory the functioning of the labor market is a derivative of the theory of general equilibrium (Gimble, 1991, pp. 625). According to this principle, the labor market mechanism serves as a "stock exchange" where workers offer their services and employers offer remuneration (salary) in exchange. The authors of neoclassical theories argue that the labor market has a regulatory factor which is price, the balance between supply and demand of labor achieved through wages. At the core of the neoclassical model of the labor market lies the relationship between wage and employment rate, where the latter is determined by supply and demand. John Maynard Keynes was the theorist of what is known as the Keynesian model who unlike neoclassical theorists argues that the labor market is unbalanced. According to Keynes, the price of labor or wages is not flexible but is fixed. According to him, it is the government that determines the necessary labor force through the economic and financial instruments at its disposal (Serena, 2016, p.206). In other words, government intervention is necessary to balance both periods of great development (economic boom) and those of economic decline. The Milton Friedman monetary model introduced in the mid-1960s has its origins in the Keynesian model according to which wages are fixed. Monetarists introduced the concept of the natural level of unemployment, where monetary policy can replace unemployment that is at the natural level. According to this theory, it is the impulses of the government budget that affect the income, consequently also affect the production or the level of employment in the short run. (Dobrescu et al., 2011). 


\section{6th International Conference on New Findings ON HUMANITIES AND SOCIAL SCIENCES}

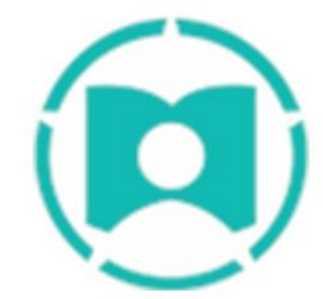

20 - 22 August 2021

Dublin, Ireland

Table. 1. The main models of creation and functioning of the labor market.

\begin{tabular}{|c|c|c|}
\hline Models & Authors & Characteristics \\
\hline $\begin{array}{c}\text { Classical } \\
\text { theory }\end{array}$ & $\begin{array}{l}\text { A.Smith } \\
\text { J.B. Say } \\
\text { J. S. Mill }\end{array}$ & $\begin{array}{c}\text { - Full employment (capital) } \\
\text { - Perfect balance between supply and } \\
\text { demand } \\
\text { - the concept of natural unemployment }\end{array}$ \\
\hline $\begin{array}{l}\text { Neoclassical } \\
\text { theory }\end{array}$ & $\begin{array}{l}\text { L. Walras } \\
\text { A. Marshall } \\
\text { V. Pareto }\end{array}$ & $\begin{array}{l}\text { - perfect balance between supply and } \\
\text { demand through wages } \\
\text { - unemployment almost non-existent }\end{array}$ \\
\hline $\begin{array}{l}\text { Keynesian } \\
\text { theory }\end{array}$ & J. M. Keynes & $\begin{array}{c}\text { - fixed salary } \\
\text { - the state determines the necessary labol } \\
\text { force }\end{array}$ \\
\hline $\begin{array}{l}\text { Monetary } \\
\text { theory }\end{array}$ & $\begin{array}{l}\text { M. Friedman } \\
\text { K. Brunner } \\
\text { A. Meltzer } \\
\text { E. Phelps }\end{array}$ & $\begin{array}{c}\text { - fixed salary } \\
\text { - lending monetary policy }\end{array}$ \\
\hline
\end{tabular}

Source. Serena, 2016, pp.207

\section{Public administration}

Hannah Arendt is among the authors offering an approach between the private and the public (the dichotomy between the two spheres) Arendt made a clear distinction between the two spheres: polis - the concept of the city-states of the Greek states - which means public and idiom - the concept of the private. In Parson (1995, pp.3) he defines public and private as res publica, ie public and res privva or personal. Parson (ivi, pp. 11-12) emphasizes that public services are defined as goods accessible to all citizens without fundamental differences. On the other hand private goods are those which are offered against the principle of supplydemand.

Definitions of public administration law vary from author to author, but the principles remain the same. A general definition of public administration law implies "the totality of principles and rules that apply to the organization and management of public administration and to the relationship between administration and citizens" (Ziller, 1993).

The concept of public administration in the 1950s was explained as "Public administration is policy-making" (Appleby 1949, pp. 169). More simply, public administration is a policymaking process. Policies cover all areas of organizing the functioning of a society. They can be economic, political, social, monetary policy, etc.

Over the years the concept of public administration has evolved. Public administration is characterized as an application of the social sciences and other sciences to public problems (Frederickson 1976, pp.152). At the core of the understanding of public administration, the basic concepts that are addressed are: publicity, application and solution of problems related to the public. This approach is based on the division between the private and the public, 


\section{6th International Conference on New Findings ON HUMANITIES AND SOCIAL SCIENCES}

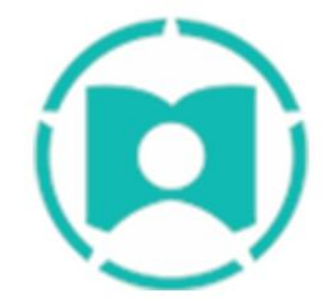

20 - 22 August 2021

Dublin, Ireland

distinguishing the latter (ie the public) as the space where all the problems of a society find solutions.

"Public administration is the study of similarities and differences in the organization, management and policy issues in order to create an institutionalized knowledge base to help make better decisions" (Guess and Gabrielyan 2007, pp.565). With this definition we will understand that public administration is the organization, management and creation of a legal basis of all activities that take place in the public sphere. Contrary to the above concepts, public administration should not be seen simply as a public space but should also be seen as a mechanism which has rules and laws of operation as well as guarantees the management of the implementation of these laws and rules.

In addition, public administration is "the bureaucratic system and its procedures that serve the government to implement its policies. Also, the field of study that describes and analyzes policy development and the implementation processes of these policies (Scott and Gordon 2009, pp.614). To understand this system of procedures we need to know that the word bureaucratic means "a body of administrative officials, procedures and tasks included in a particular system of administration" (Ivi, p. 53). This is an approach through which the concept of public administration is based on the procedures and rules that a government follows to implement its policy. The bureaucratic system is nothing but a mechanism composed of administration officials, the tasks they have and the procedures we use to ensure that the implementation of government policy is complete.

Public administration equals policy plus management is a more realistic concept (Holzer et al 2007, pp.69). This is a simpler and more direct understanding of public administration which encompasses two concepts: poltics and management. By "politics" we will understand the relationships between factors in public life that are built by people, government, lawmakers, etc. And with "management" we will understand the control and organization of activities that are influenced by public factors based on the rule of law. In everyday use, concepts such as public administration, state administration, bureaucratic administration, executive administration, etc. are often encountered. In some cases these concepts are defined in the same way and in some other cases they are given different definitions. It is important to understand that "state" as a notion is the largest organization in contemporary societies that coordinates relations between people. It carries out all this activity through the government and administration (Pajaziti 2009, pp.698). We must first specify that the public administration has the opposite of the private administration because of the scope of action, the public, and because of the fact that public administration is in the general interest, ie for all factors operating in a society. The elements that make a public administration as opposed to the private one not only in the formal sense are:

1. The law (legal space) that guarantees it.

2. Competencies determined by law.

3. The purpose of operation related to the facility and public activity.

4. The activity of public bodies to be guaranteed by the constitution (basic law) 


\section{6th International Conference on New Findings ON HUMANITIES AND SOCIAL SCIENCES}

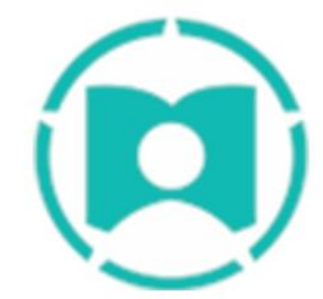

20 - 22 August 2021

Dublin, Ireland

In this context, the state activity of each country is exercised on the basis of the so-called "state administration". According to E. Dobjani (2007, pp.15) state administration is presented in two basic forms:

1. in the form of a state instrument (formal, organizational meaning)

2. in the form of state activity (material, functional meaning)

Although the presentation of the state administration can be in two forms, it is impossible to make a division between them. Its formal-organizational meaning as an instrument cannot exclude the material-functional meaning as an activity. In other words, there can be no instrument without activity, just the opposite, there can be no activity without an instrument, at least when we talk about state administration.

Within the European Union, the principles of administrative law are based on: "reliability and predictability, open and transparent administration, accountability, efficiency and effectiveness" (OECD 1999, pp. 8-13). The principles of administration do not operate in vacancy. They must be secured through legal and institutional procedures, implemented within a legal framework of law as well as have mechanisms for monitoring, enforceability and evaluation of their implementation.

\section{Aspects of public administration in Albania}

Public administration is one of the most important (if not the most important) sectors for the functioning and regulation of all social activities in a state organizational structure.

The population of Rep. of Albania is estimated at 2,829,741 inhabitants (INSTAT, January 1, 2021) of which the workforce is estimated at 1,218,000 (ibidem). Of the total workforce, there are 175,443 employees engaged in the public sector (INSTAT, 2020), of which 14,228 are engaged as senior officials, managers or legislators, 77,232 are employed as public administration specialists, 35,556 are engaged as technicians and specialist assistants, 14,305 are employed as simple clerks and 33,122 are employed as workers in the administration. The percentage of the number of public administration employees is $14.4 \%$ of the number of labor force in the Republic of Albania.

Public administration in Rep. of Albania is regulated on the basis of the law "on the organization and functioning of public administration" (Official Bulletin of the Republic of Albania 2012, law no. 90). This law defines the functions, principles, typology of the organization of public administration, internal organization of public administration, supervision of public administration, coordination and cooperation in public administration and delegation of functions of public administration. In the sense of the law, public administration is "the organizational and professional apparatus, which serves the public interest impartially, by implementing the legislation in force, performing public services and drafting and implementing general state policies" (Ivi, pp. 7695). The basic principles on which the public administration operates in Rep. of Albania are the principles of:

- unity and hierarchy;

- accountability; 


\section{6th International Conference on New Findings ON HUMANITIES AND SOCIAL SCIENCES}

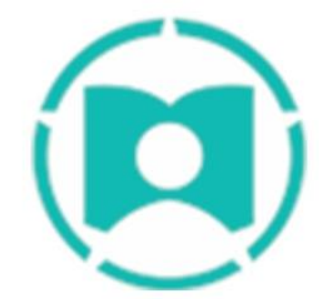

20 - 22 August 2021

Dublin, Ireland

- deconcentration;

- clarity in defining and allocating responsibility;

- economy,

- efficiency and effectiveness,

- as well as cooperation between state administration institutions "(ibidem.).

The code of administrative procedures' purpose is the realization of the functioning and the implementation of the activity of the public administration (Official Bulletin of the Republic of Albania 2015, law no. 44). This code, in addition to regulating the functioning of the public administration activity, protects the interests and rights of individuals engaged in relations with the public administration, based on the regular law enforcement processes. The institution responsible for ensuring a professional, stable administration, based on the principles of meritocracy and political impartiality is the Department of Public Administration (Official Bulletin of the Republic of Albania 2013, law no. 152, article 7).

The main areas covered by the Department of Public Administration ${ }^{2}$ in the Republic of Albania are:

- management and implementation of the civil service in all central administration institutions;

- drafting and implementing policies in the field of salaries and building public administration institutions;

- design and implement general training policies and programs applicable to the public administration as a whole.

The functioning and areas covered by the Department of Public Administration provide for the warranty and implementation of government policy within the civil service framework ensuring that public administration institutions guarantee all the principles of unity, accountability, efficiency and effectiveness as well as inter-institutional cooperation.

The basis of the functioning of the public administration in Albania are the principles that guarantee its functionality. Then public administration should be seen as a public service which takes place within a public space consisting of an administrative system, administrative officials providing the best administrative services. At its core remains the modernization and achievement of the best standards to adapt to the instruments of functioning of public administration in the countries of the European Union.

In order to guarantee the functionality of public services (in other words guaranteeing the functionality of public administration) the organization of public administration has faced periodic changes based on reforms that have affected public administration. Public administration reform (Decision of the Council of Ministers, no. 1017) in Albania has been a necessary and continuous process, closely linked to the process of integration into the European Union (EU). Public administration reform has been one of the priorities of the Albanian

\footnotetext{
2 (www.dap.gov.al, seen on May 10, 2021)
} 


\section{6th International Conference on New Findings ON HUMANITIES AND SOCIAL SCIENCES}

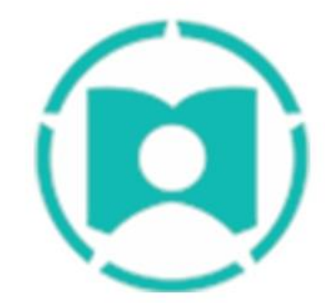

20 - 22 August 2021

Dublin, Ireland

governments as a key instrument for improving the quality of services to citizens and business and as a condition for the country's integration processes.

\section{Conclusion}

This paper on "conceptualization of the labor market and public administration.Public administration in Albania " reflected on two concepts such as the concept of labor market and the concept of public administration. Important aspects of public administration in the Republic of Albania were addressed in support of both theoretical concepts.

First, the labor market encompasses a broader concept than public administration itself. For this reason labor market theories were presented at the top of this paper. In this paper the main theories of the labor market were rationalized only to the classical theories of the labor market. Thus the main theories of the labor market are: classical theory, neoclassical theory, Keynesian theory and monetary theory. The conceptualization of labor market theories was analyzed based on the definitions of various authors on the labor market. In other words, labor market

- means the relationship between employer and employee;

- is a means of communication through which sellers and buyers will need to inform each other about what they own, what they need and the prices they ask or propose, before closing a transaction.

- described as the juxtaposition of labor supply and demand in a given time span and in a geographical area that usually ends through employment.

Second, the conceptualization of public administration is narrower than the labor market concept itself. In fact public administration is part of the labor market. Public administration is the public space where the bureaucratic activity of a government takes place. Even in this case the conceptualization of public administration was defined on different approaches such as:

- public administration is policy-making;

- public administration is the study of similarities and differences in the organization, management and policy issues in order to create an institutionalized knowledge base to help make better decisions;

- public administration is "the bureaucratic system and its procedures that serve the government to implement its policies;

- public administration equals policy plus management.

Third, the public administration in the Republic of Albania was treated in several aspects such as the space (weight) occupied by the public administration in the labor market in Albania, the distribution of employees engaged in the public sector, the law that guarantees the functionality of public administration in Albania, the basic principles of the functionality of the public administration and the department of public administration as the most important structure of guaranteeing the functioning of the public administration. 


\section{6th International Conference on New Findings ON HUMANITIES AND SOCIAL SCIENCES}

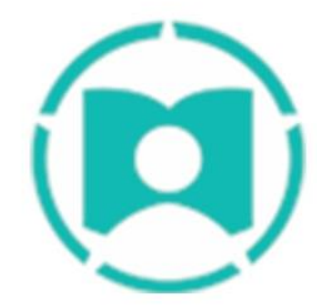

20 - 22 August 2021 Dublin, Ireland

Public administration is one of the most important sectors for the functioning and regulation of all social activities in a state organizational structure. With the share of $14.4 \%$ of the labor force in the Republic of Albania, the public administration sector should be in focus of achieving the provision of public service according to the standards of public administrations of the European Union countries.

\section{References}

For each work shown in the list of references must be a reference in the text. All citations in the text and all references must meet APA styles (American Psychological Association 7th edition - more information http://www.apastyle.org/).

Appleby, P., (1949), "Policy and Administration" University of Alabama Press, USA.

Beligrădeanu, Ş. and Stefănescu, I.T., (1997), "Labour law dictionary”, Ed. Luminalex, Romania.

Cojuhari, A. and Dorofeev, L., (2014), “Concept issues regarding the labour market and its reflection in Republic of Moldova", Economic Journal, no. 3 (89).

Dobjani, E. (2007), "E drejta administrative 1", botim i ripunuar, Shtypshkronja "Perlat Voshtina”, Tiranë, Shqipëri.

Fincham R. \& Rhodes P.S., (1988), "The individual, work and organization: behavioural studies for business and management students", Weidenfeld and Nicolson, London, UK.

Dobrescu, M., Paicu, C., Iacob, S., (2011), "The natural rate of unemployment and its implications in the economic politics plan", Theoretical and applied economy, Volume XVIII (2011), No. 2 (555).

Didier M., (1997), “The economy: rules of the game”, Ed. Humanitas, Romania.

Frederickson, H. G., (1976), "The lineage of new public administration: Administration and Society", (8). pp.152.

Gimble D. E., (1991), “Institutionalist Labor Market Theory and the Veblenian Dichotomy", Journal of Economic Issues, Taylor \& Francis, Ltd., UK, Vol. 25, No. 3, pp. 625-648.

Guess, M.G. and Gabrielyan V., "Comparative and International Administration” pg.565 in: Rabin J., Hildreth W.B and Miller J.G., (2007), "Handbook of Public Administration", third edition, Taylor and Francis, USA.

Holzer M., Gabrielyan V., and Yang. K., "Five Great Ideas in American Public Administration", pp. 69, in: Rabin J., Hildreth W.B and Miller J.G., (2007), "Handbook of Public Administration", third edition, Taylor and Francis, USA. 


\section{6th International Conference on New Findings ON HUMANITIES AND SOCIAL SCIENCES}

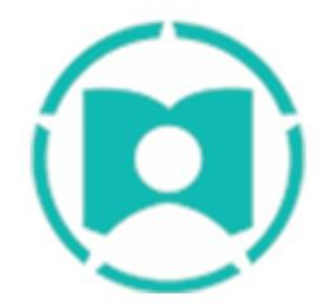

20 - 22 August 2021 Dublin, Ireland

Hudson Ch. K., (2000), "Poverty and the Secondary Labor Market", Chapel Hill, UK.

Institute of Statistics, INSTAT (2019), “Labor force balance 2015-2019”, Tirana, Albania.

Official Bulletin of Republic of Albania, law, No. 90/2012, "For the organization and functioning of the state administration", Official Publishing Center, no. 135, Tirana.

Official Bulletin of Republic of Albania, Decision of the Council of Ministers, no. 1017, datë 18.9.2009, "For the approval of the cross-sectoral strategy of public administration reform", Official Publishing Center, Tirana.

Oxford Dictionary, (1987), "The popular Oxford Dictionary", sixth ed., Oxford University Press, UK.

OECD, (1998), "Parime Europiane për Administratën Publike", Zyra e Publikimeve të OECD/ SIGMA nr. 27, Paris, Francë.

Pajaziti, A. (2009), “Fjalor i Sociologjisë”, Logos-A \& SEEU, North Macedonia

Parsons Wayne, (1995), "Public Policy: An introduction to the Theory and Practice of Policy Analysis” Edward Elgar Publisher, UK.

Samuelson P. A. and Nordhaus W. D., (2001), "Political economy”, Ed. Teora, Bucureşti, Romania.

Scott J. and Marshall G., (2009), "Oxford Dictionary of Sociology", third rev. ed., Oxford University Press, UK.

Serena, P.C., (2016), “Labour market - concepts, functions, features, patterns", Revista Strategii Manageriale nr. 4, Romania.

Smith, S. (2003), "Labour Economics”, second ed., Routledge, London, UK.

Reich M., Gordon D. M. and. Edwards R. C., (1973), "The American Economic Review”, Papers and Proceedings of the Eighty-fifth Annual Meeting of the American Economic Association, American Economic Association, Vol. 63, No. 2, pp. 359.

Ziller, J., (1993), “Administrations comparées: les systèmes politico-administratifs de l'Europe des Douze", Montchrestien, Paris. 